\title{
A Review of Governmental Intervention on Sustainable Housing Provision for Urban Poor in Nigeria
}

\author{
Ebehikhalu O. Nicholas ${ }^{1} \&$ Dawam D. Patrick ${ }^{1}$ \\ ${ }^{1}$ Department of Geography and Environmental Management,University Of Abuja, Fct, Abuja, Nigeria. \\ Correspondence: Ebehikhalu O. Nicholas, Department of Geography and Environmental Management,University Of
} Abuja, Fct, Abuja, Nigeria.

Received: May 15, 2015

Accepted: May 29, 2015

Available online: September 2, 2015

doi:10.11114/ijsss.v3i6.1069

URL: http://dx.doi.org/10.11114/ijsss.v3i6.1069

\begin{abstract}
Earlier studies investigating housing policies In Nigeria have not explicitly considered the level of implementation of housing policies goals despite the facts that housing policies dictate the nature of development of housing in the country. This paper therefore examined the various interventions of government on sustainable housing provision in Nigeria. A detailed literature review on the existing housing policies and programmes in Nigeria was carried out. This was done with a view to determining the level of implementation of the housing policies, identifying the various problems militating against the achievement of the goals of housing policies and suggesting possible recommendations towards addressing the problems.
\end{abstract}

Keywords: Development, Housing and Sustainable Housing.

\section{Introduction}

Housing is a significant factor in gauging a country's development. Housing can be considered as both economic and social responsibilities of ensuring members of a society have a home to live in.

Housing is a major part of a nation's wealth, and plays a major role in economic development (Aluko, 2004). As succinctly put by UN- Habitat (2012), housing is one of those basic social conditions that determine the quality of life and welfare of people and places. There are two interrelated functions of housing: housing as a physical structure residential buildings/shelter, their design, material qualities, their arrangement in space, and their ecological interactions with the physical environment; and housing as a social structure - residence based activities, their character, social qualities, and their socio-economic interactions in space with the immediate communities and wider society.

Despite the fundamental importance of housing, adequate supply has remained a major problem. According to Ademiluyi (2010), in spite of the fundamental roles of housing in the life of every individual and nation, and in spite of the United Nation's realization of the need to globally attain adequate shelter for all, the housing crises remain among the global problems and a grave and rising challenges facing urban and some rural residents, particularly in most developing countries. Successive governments of Nigeria have proffered various housing delivery policies and strategies for improving housing delivery in Nigeria. Various government interventions and huge investments in housing provision have been on since even before Nigeria gained political independence in 1960. Despite all the interventions and investments in the housing development, housing problem in Nigeria still remain incurable as majority of Nigerians still lack access to housing. It becomes imperative therefore to check the various policies of government over the years once again so as to identify why the policies have not been able to achieve its goal of housing provision. This will enable suggestion of corrective measures which are needed towards ensuring endurable practical solutions to the housing problems.

\section{Research Methodology and Study Area}

\subsection{Research Methodology}

The research method adopted is a qualitative analysis of secondary data related to the study. Secondary sources of data including internet, textbooks, journals, conferences, proceedings and newspapers were explored to review some underlying theoretical issues from previous researches. Thus, a review of literature on housing policies for sustainable housing development for the urban poor in the urban areas was done. The analysis of the body of data provides the 
evidence that justify government intervention and government failure on the provision of housing in Nigeria. It is imperative as it provides the basis for proposing the application of sustainability principles to the housing provision.

\section{Brief History of Nigeria}

The name "Nigeria" which was first mentioned by a Journalist - Flora Shaw was derived from "Niger River" in the late $19^{\text {th }}$ century. Nigeria is located in West Africa and shares land borders with the Republic of Benin in the west, Chad and Cameroun in the east, and Niger in the north. Its coast in the south lies in the Gulf of Guinea in the Atlantic Ocean. It land mass extends from the Gulf of Guinea in the south to the Sahel (the shore of the Sahara Desert) in the north. Nigeria has a total area of $923,768 \mathrm{~km} 2$ making it the world's $32^{\text {nd }}$ largest country (after Tanzania). Nigeria lies between latitudes 4 and $14 \mathrm{~N}$ and longitudes 2 and $15 \mathrm{E}$. the main rivers are Niger and Benue which converge and empty into the Niger Delta. Niger Delta is one of the world's largest river deltas, and the location of a large area of Central African Mangroves. Nigeria is divided into thirty six States and one Federal capital Territory, which are further subdivided into 774 Local Government Areas (LGAs). Abuja, the capital city of the Federal Republic of Nigeria, replaced the former capital city, Lagos, in December 1991, because of its more central location, among other reasons. Nigeria is the most populous country in Africa and indeed in black nation of the world with a population of 140 million people, based on the 2006 National Population Census. The total population of Nigeria was last recorded at 166.2 million people in 2012 from 45.2 million in 1960. The figure below is a map of Nigeria.

\section{A Review of Housing Policies in Nigeria}

\subsection{Pre Colonial (before 1900)}

During the pre-colonial period, a communal system of housing delivery was practiced in most Nigeria communities. Houses were built through communal efforts by members of age group, peer groups and among others. That is, members of any of the groups would on appointed day come enmass to assist the builder in whatever way to build. The builder would in return, provide sumptuous meals as long as the task of the building last. However, the housing were structurally unsound because of poor building materials, poor building technology and methodology.

\subsection{The Colonial Period (1900-1960)}

The colonization of Nigeria by the British marked the beginning of the direct government involvement in the provision of housing units in the country. During the colonial period, the finance of housing was provided and limited to the expatriate staff and few selected indigenous senior civil servants working with the colonial masters. Government intervention and involvement were centered basically on the provision of planned residential quarters for expatriates staff and selected indigenous staff of specialized occupations without conscious efforts to construct houses for the general public or build houses either for sale or rent to the general public. This period spurned the birth of the Government Reservation Areas (GRAs) which had basic infrastructural facilities. According to Abimbola (2010), in the early 1900s government policy on housing by the Lord Luggard administration contained guidelines for laying out townships, construction of houses, maintenance of specified housing standards in the "European Reservation" and the "Native quarters." Further contribution was made in the 1920s following the outbreak of bubonic plague in Lagos in 1928. This necessitated the establishment of the Lagos Executive Development Board (LEDB) which served as the main organ for town planning and housing development with particular attention to GRA.

The basic idea in the GRA policy was to provide habitable housing and housing environment for those expatriate administrators comparable to the best in their respective countries. Their housing quarters were well planned, with all possible comfort, services and amenities; including water, closed sewers, electricity, and abundance of open space and recreational areas. The idea of housing policy was thus initiated and implemented in Lagos and in regional and provincial capitals throughout the country (Ukwayi et al, 2012). Meanwhile, Nigeria Building Society (NBS) was introduced. Waziri and Roosli (2013) stated:

"during the period under review the colonial administration established the Nigerian Building Society (a replica of what was obtainable in the British system where mortgage bank was known as building society) after the second world war. This was to allow for housing opportunities within both the public and private sectors. However, the NBS remained solely dependent on the government funding and as such could not stand the test of time."

The workers strike of 1945 gave rise to a further government commitment to housing. The period of the Second World War and the Nigeria contribution to the war made Nigerian nationalists more restive and no doubt, had an effect on the Nigerian situation. In the year of the end of the Second World War, the workers' strike occurred and the problem of housing shortage featured prominently. The government was committed to building workers' houses and this was eventually sited at Surulere in Lagos and in other parts of the country, no such spectacular intervention was recorded. Between 1900 and 1946 a programme of land reclamation was pursued vigorously by government in Lagos, thus swamp areas in Yaba, Oko Awo and Apapa were reclaimed. An area of nearly 1000 acres was reclaimed in Lagos. Some 
of these areas reverted to private entrepreneurship for housing development. The Yaba Garden City, though not a reclaimed area was a government layout, part of which was developed through private financing. After the second war with series of agitation, it became obvious that independence would soon be granted to the country following the internal self-government of 1956. The question then arose as to the fitness of Lagos, in view of the squalid appearance of its central area, for the celebration which would be inevitable at the attainment of independence by the country. Something had to be done to face lift Lagos and the Lagos central planning scheme law of 1955 was enacted which brought the Central Lagos Slum Clearance Scheme into effect and this provided for the slum clearance of the centre of Lagos and the resettlement of the residents of the area to be cleared. Such residents were to be housed temporarily in Surulere and this was the genesis of the famous Surulere Re-Housing Scheme and of housing development in the country (Fadahunsi, 1985).

Towards the end of colonial rule, regional system of government was adopted, and each region formulated housing policy. The agency responsible for administering housing was the Regional Housing Corporation (RHC) founded in 1958. The RHC's duties included laying out housing estates with infrastructure, allocating the plots to those who could afford to build, construction of model houses with modern amenities for sale or rent, and provision of loans to individuals to build. Only some middle and high income groups benefited from these initiatives (Abimbola, 2010). It was found that like the Nigerian building society, the regional housing corporations had impacts only in the then capital cities of the respective regions; Kaduna, Enugu, and Ibadan. One of such is the Bodija Estate in Ibadan developed by the defunct Western Regional Government (NHP, 1991).

In Lagos the government was executing housing through the LEDB. Housing estates were developed in Apapa, Surulere and Victoria Island, again only middle class and high income groups benefited from these initiatives. One of the responses to housing the urban poor in Lagos was the 1955 slum clearance in the central Lagos. About 1,300 low income one or two bedroom units were provided for low income families in Surulere, but many slum dwellers refused to move to the apartments due to high prices placed on the housing (Marris, 1961, 1985 and Abimbola, 2010).

\subsection{Post Colonial Period}

The post-independence governments in the country did not fare better than the colonial governments in terms of housing provision for the public. The concept of Government Residential Areas (GRAs) was not only retained but was embraced and protected with greater zeal by the new Nigerian administrative and political elites. Those who took over government successively saw it as a mark of distinction to stay in GRA. The period placed emphasis on the five yearly development plans as an instrument for growth and development.

\subsubsection{First National Development Plan}

During the first national development plan period (1962-1968), the federal government made some efforts to provide housing. According to Onibokun (1985), although the federal government made some efforts at improving the housing situation during this period, it can generally be said that housing was given a very low priority in the development plan. Housing was grouped with town and country planning and funds allocated for this sector were very small. Government activities on housing were confined to regional capitals like Enugu, Kaduna Ibadan and Benin City where staff quarters for senior officials were built. The State Housing Corporation was established in the then regions. The achievements of the housing corporation during this period did not have much overall impact due to lack of funds and technical personnel.

\subsubsection{Second National Development Plan}

During the second national development plan period (1970-74), the federal government showed a serious direct involvement in the construction of housing units, but the amount budgeted for housing development was very low (Adedipe and Lasisi, 2005). Inspite of the critical housing situation which was worsened by the civil war, housing was still grouped with town and country planning with a meager allocation of about 49 million naira.

In 1971, long after independence, the National Council on Housing was established and in 1972 embarked upon the National Housing Programme with the aim of providing affordable housing for all income groups and to achieve a housing situation in which an average worker would not have to pay more than $12 \%$ of his monthly income on rent. However this policy has not yielded the desired results due to what Mabogunje (2003) listed as problems confronting housing provision in Nigeria as: (i) problems of inadequacy of housing unit distribution, (ii) high cost of building materials, (iii) inappropriate technology, (iv) unavailability of mortgage funds and housing loans, (v) the land use system, (vi) infrastructure development and (vii) rural to urban migration.

The Federal Housing Authority (FHA) was established through the promulgation of decree no. 40 of 1973 and began a formal operation in 1976. Part of its responsibility was making proposals to the federal government on housing and ancillary infrastructural services and implementing those approved by government. Since inception, FHA has been the 
main public organ in the provision of housing in Nigeria. For instance between 1975 and 1980 under the national housing programme, FESTAC Town was developed preparatory to 'First all African Festival of Arts and Culture (FESTAC)'. Ipaja Town, the Amuwo Odophin Phase 1 Estate, all in Lagos and first ever low cost housing estates in the eleven state capitals were also developed. This marked the first major federal government effort in providing affordable housing to Nigerian citizens on long term mortgage repayment arrangement. The Nigeria Building Society which was hitherto the brain child of the British Administration was transformed or metamorphosed into Federal Mortgage Bank of Nigeria (FMBN) in 1977. This Federal Mortgage Bank of Nigeria served as the main engine room for public housing delivery with a dual function of both primary and secondary mortgage institution (Waziri and Roosli, 2013).

\subsubsection{Third National Development Plan (1976-1980)}

The most significant government intervention was on housing during the third national development plan of 1976-1980 when the federal government participated directly and actually in the provision of housing rather than leaving it to the private sector. Thus a total of N2.6 billion was allocated for the implementation of the programme (Federal Republic of Nigeria, 1981). Between 1975 and 1980 there was a plan of delivering 202,000 housing units to the public but only 28,500 units, representing $14.1 \%$ was achieved (Adenuga, 2013).

\subsubsection{Forth National Development Plan (1980-1985)}

The 1981/82 national housing programme was designed to provide 350 medium and high income housing units in each of the then 19 states of the federation by the FHA. This was in addition to the national low income housing programme embarked upon by the governments in all the states of the federation popularly known as Shagari Low Cost, under the supervision of Federal Ministry of Housing and Environment (NHP, 2006). During this period, government embarked on an elaborate housing programme, a proposed number of 40,000 housing units were to be constructed all over the federation annually with 2000 units per state including Abuja, the Federal Capital City. The estimated target for housing delivery under this policy was 200,000 between 1981 and 1985 but only 47,500 were constructed across the 19 states of the federation including Abuja, the Federal Capital Territory (Adenuga, 2013). Table 1. shows the details of housing delivered in the period of 1980-1983 ranging from one bedroom to three bedroom flats (Waziri and Roosli, 2013). In 1981 government redirected its efforts on infrastructure and housing provision including social amenities such as schools, health centres, and shopping centers to establish viable communities. The federal government encouraged companies with more than five hundred workers to provide housing, and the commercial banks to set aside $10 \%$ of their loanable funds for housing purposes (Abimbola, 2010). This period witnessed a tremendous increase in the interest and involvement of public sector in shelter delivery, and the importance of the shelter sector within the overall economy. Most of the strategies and activities during these periods were seen to be in conformity with enabling concept, and public production of shelter remained their common feature. The period witnessed huge failures, when government allocated N1.9 billion for housing construction, in all the twenty states of Nigeria, including Abuja. By june 1983, N600 million (37.5\%) was only spent to complete only 32,000 units, yielding an overall achievement level of just $20 \%$.

\section{$4.41985-2000$}

During this period an ambitious housing policy was launced by the then military government in 1991 with a slogan housing for all by the year 2000AD. The goal was for all Nigerians to have access to decent housing at affordable cost before the end of the year 2000AD. The housing needs in the country as at the launch of the policy, stood at about 8 million units including projections in meeting the policy target in both rural and urban centers in response to United Nations Advocacy which calls for housing for all by the year 2000AD. The policy estimated that 700,000 housing units were to be built each year if housing deficit was to be cancelled of which about $60 \%$ of the houses were to be built in urban centers. The policy restructured the financial routing of accessing housing loans by way of creating a two tier financier structure, which were the Federal Mortgage Bank of Nigeria (FMBN) as the apex and supervisory institution and Primary Mortgage Institutions (PMIs) as primary lenders. The Federal Mortgage Bank of Nigeria was empowered through Decree No. 82 of 1993 to collect, manage and administer contributions to the National Housing Fund (NHF) from registered individuals and companies. The NHF was initially meant to facilitate the now discarded vision of housing for all by the year 2000AD which was long being overtaken by events. Accordingly, with Decree No.3 of 1992, the NHF was to operate under a situation that inter alia included the provision that all Nigerian workers earning an annual income of N3, 000 and above should contribute $2.5 \%$ of their salaries to the fund. In order to ease the pooling of funds and facilitate access by the workers, the laws empowered employers to remit the mandatory contributions to the Federal Mortgage Bank of Nigeria. Commercial and merchant banks were mandated by the same law to invest $10 \%$ of their loans and advances into the FMBN, while insurance companies were expected to contribute 20 and 40 percents of their non-life and life funds into real estate development as a means of further easing the housing problems. The laws also required the three tiers of government (Federal, State and Local) to contribute at least $2.5 \%$ of their annual revenues into the NHF. The maximum loans allowed for a contributor was pegged by the decree at one and half a 
million naira $(\mathrm{N} 1,500,000.00)$ and to be jointly provided or financed by both the PMIs and the FMBN. The loans were given at half or fifty percent of the prevailing market rate. There were also plans in 1994 under the NHF to deliver about 121,000 housing units but less than 5\% were recorded to have been achieved (Waziri and Roosli, 2013).

\subsection{0 - Date}

The poor performance of the national housing policy in meeting its set goals and objectives led to the comprehensive review, which culminated in the housing and urban development policy of 2002. The new national housing policy was proposed in 2002, and its first draft came into publication in January 2004. The major thrust of the housing and urban development policy was to meet the quantitative housing needs of Nigerians through mortgage finance. The policy was revised in 2004 entailing strategies for housing provision and the institutional framework for it. As proposed by the "Presidential Technical Committee on Urban Development and Housing," the framework for its operation involved restructuring of existing structures and creation of new ones (Ukwayi et al, 2012).

In 2013 the Government had a programme of "Own a House with your Rent" -where the Federal Government would be building five bedroom duplex, four bedroom duplex detached, four bedroom duplex semi detached, three and two bedroom flats to be acquired by public and private sectors workers resident especially in Abuja for $\# 46 \mathrm{~m}, 38 \mathrm{~m}, 34 \mathrm{~m}$, $12.42 \mathrm{~m}$ and $10.44 \mathrm{~m}$ respectively. Interested workers would make a down payment of $36 \%$ for the $46 \mathrm{~m}, 38 \mathrm{~m}$ and $34 \mathrm{~m}$ category and $10 \%$ for the $12.42 \mathrm{~m}$ and $10.44 \mathrm{~m}$ category. It gave 15 -20years period to repay the balance after down payment. But the first and most crucial issue was how a normal or average public servant could make the required down payment given his meager salary. It becomes imperative for the government to know that no public servants who decently and sincerely rely on his salary cannot afford the down payment. The prices of houses are too high and besides given the salary package of the Nigerian public servant; - can their paltry annual rent pay up the balance? Over $1,107,000$ public servants work in the Federal Civil Service contributing a monthly average of at least \#500 to the NHF. This gives about \#7billion annual contributions. What has government done with this contribution yet Nigeria's housing deficit is still estimated at about 17 million houses to cost \#56.9 trillion according to World Bank. So to what extent, on yearly basis has NHF been able to reduce this colossal deficit? (Africa Herald Express, 2014).

Nigeria' development Strategy, Vision 2020 projects, targeted a construction of 10,398,650 housing units from 2012 to 2020 (Table 2. ) which amounts to $1,155,406$ housing units per annum. At an average cost of about US\$50,000 per house, the annual required investment in housing amounts to US\$57,770,300,000 (fifty seven billion, seven hundred and seventy million, three hundred thousand dollars). Meanwhile the current funding from housing financiers is not more than US\$2billion per year, still leaving a funding gap of over US\$55 billion per annum. The New National Housing Policy specifically provides for an annual target of 1,000 housing units per annum by each state government. This requires an annual investment of at least US\$50million by each State government. For the 36 state governments, the investment sums up to about US\$1.8 billion per annum and the State Housing Corporations are seeking opportunities for a Secondary mortgage lender to support them (Policygnosis International Policy and Financial Advisory, 2011).

\section{Sustainable Development and Sustainable Housing}

Sustainable development is described as economic progress which meets all our needs without leaving future generations with fewer resources than the present generation enjoys. For wealthy nations sustainable development means policies concerning issues such as recycling, energy efficiency, conservation, rehabilitation of damaged landscapes. Whereas, for the poor countries, it means policies for equity, fairness, respect for the rule of law, redistribution of wealth and wealth creation (Oyeshola, 2008). Sustainable development is a new way of life and approach to social and economic activities for all societies, rich and poor which is compatible with the preservation of the environment (Lele, 1991). The world commission on environment and development (WCED. 1987, p. 8) defined sustainable development as development that meet the needs of the present without compromising the ability of future generations to meet their own needs (Choguill, 2007).

Housing is key to sustainable development. That is why UN Habitat (2012a) wrote:

"housing is one of those fundamental social conditions that determine not only the quality of life and welfare of the people but also that of places. It follows that where homes are located, how well designed and built, and how well they are woven into the environmental, social, cultural and economic fabric of communities are factors that, to a large extent have overbearing effects on the daily lives of people, their health, security and wellbeing, and which, given the long life of dwellings as physical structures, affect both the present and future generations."

Sustainable houses are those that are designed, built and managed as: healthy, durable, safe and secure; affordable for the whole spectrum of incomes; using ecological low-energy and affordable building materials and technology; resilient to sustain potential natural disasters and climatic impacts; connected to decent, safe and affordable energy, water, 
sanitation and recycling facilities; using energy and water most efficiently and equipped with certain on-site renewable energy generation and water recycling capabilities; not polluting the environment and protected from external pollutions; well connected to jobs, shops, health-and child-care, education and other services; properly integrated into, and enhancing, the social, cultural and economic fabric of the local neighborhood and the wider urban areas; and properly run and maintained, timely renovated and retrofitted (UN HABITAT, 2012).

\section{Challenges of Housing Policies and Sustainable Housing Development in Nigeria}

If sustainable housing development is achievable in Nigeria, there is need to identify the problems that have led to the failure of development policies. Government is the most important factor in the housing policies; hence government must hold accountability more seriously. In a country where the government itself is corrupt there is no amount of discipline that can be preached on accountability in the policy implementation (i.e. accountability cannot be demanded of those implementing the policies).

The government has failed to build for the nation a solid platform for various sources of housing finance such as life insurance reserves, commercial banks, savings and loan institutions and primary mortgage institutions. Although these various sources exist, they have not played significant role in housing development in the country. For example, the high interest rates on loans from commercial banks and inability of the Federal Mortgage Bank of Nigeria (FMBN) to provide adequate mortgage facilities have made their roles on housing development insignificant or negligible. Government and individual savings still remain the main sources of housing finance. This is why the bulk of housing stock in the country is constructed through government and individuals efforts. Right from the post independence era, public housing schemes in the country were funded mainly through revenue allocations from government and due to fiscal and budgetary constraints, government have been forced to reduce drastically the level of financial support for the execution of public housing projects.

Lack of consistency and continuity in government policies and programmes is another problem that has had detrimental effects on housing policies in Nigeria. This has been a commonplace practice among the various governments in Nigeria where every new administration or government comes with new policies and programmes without resort to what previous administration had done or left behind. Consistency and continuity in housing programmes are substances for sustainable housing provision and development.

Unstable political climate does not provide a platform for sustainable housing development. Nigeria is a country which over a long period of time has been bedeviled by uncertainty of political atmosphere and unpredictable political climate. This has weakened the structures and the institutional framework for housing delivery. Housing programmes have been politicized to the extent that the ruling political parties use housing programmes to secure patronage from the citizens and reward political loyalists by allocating and awarding contracts for housing projects on political basis. Most governments at state level have not been willing to support the implementation of housing policies and programmes initiated by federal government particularly where they are not in the same political parties.

High rate of population growth and urban expansion has been another problem that has posed a serious challenge to the realization of sustainable development of housing. Population growth in Nigeria is much faster than the number of houses being constructed. Overcrowding and congestion, increasing rate of unemployment, pressure on the inadequate and already overstretched infrastructure are products of urbanization. Urbanization has been a clog in the wheel of realizing the policies and programmes of housing.

The participation of the people and the definition of housing needs have never been considered in the formulation and implementation of the policies and programmes of housing but informed by mere speculations, selfish political interests and as an investment commodity for profit making. The poor people have not been heard by the decision makers and hence they have no influence on matters that affect their destinies and future

\section{Conclusion and Recommendations}

Housing policy package designed to achieve sustainable housing would necessarily have to be designed to meet the following recommendations:

The government should build for the nation solid sources of housing finance such as life insurance reserves, commercial banks, savings and loan institutions and primary mortgage institutions. This will improve the housing provision for urban poor in Nigeria.

Housing policies must provide the basis for household improvement through public participation particularly the lower income groups. There is therefore the need not only for the government to accommodate the participation of the people in formulation of the housing policies and programmes but also in the implementation of the housing policies and programmes. 
Continuity and consistency in housing policies and programmes should be encouraged Nigeria.

Nigerian Political leaders should ensure a stable political atmosphere since housing policies and programmes can only produce better results in a stable political atmosphere.

The thesis of sustainable housing development therefore posits that the present series of policies have been wasteful because the policies have been implemented with high level of corruption, inequitability, inconsistency and underfunding. The government is therefore urged to pursue a new development strategy that can both ensure continue housing growth and development devoid of corruption, inequalities with and among the people and restructuring of the policies to guarantee an equitable distribution of housing. In the immediate form, the policy objectives and targets should be set with the belief that the basic needs of all can and must be met, now, as a matter of people's fundamental rights. Every Nigerian has a right to basic needs such as house. In essence development of basic needs like housing cannot be anything but the 'the fundamental responsibility of government and the basic rights of citizens.' If the recommendations are developed and implemented, major constraints on meeting housing needs for sustainable housing development would have been overcome.

\section{References}

Abimbola, A. (2010). Sustainable Strategies for Housing the Urban Poor: A Case Study of Lagos, Nigeria. Policy and the Environment, 90-95.

Abiodun, J. O. (1983). Housing Problems in Nigerian Cities. Third World Planning Review, 5(3), 339-347.

Adedipe B. O. and Lasisi A. L. (2005). The Challenges of Sustainable Provision of Urban Housing in Nigeria: A Case Study of Ilaro, Ogun state. In The Built Environment: Innovation, Policy and Sustainable Development, edited by Okewole A., Daramola A., Ajayi A., Odusami K. and O. Ogunba, 67-71. Ota: Covenant University.

Adenuga, O.A. (2013). Factors affecting Quality in the Delivery of Public Housing Projects in Lagos State, Nigeria. International Journal of Engineering and Technology 3(3): 332-344.

African Herald Express (2014). Africa Herald Express. [Online URL: www.africanheraldexpress.com/blog8/.... ] accessed on November 6, 2014

Agbola, T. (1998). The Housing of Nigerians: A Review of Policy Development and Implementation. Ibadan: DPC

Agbola, T. (2002). The Housing of Nigeria: A Review of Policy Development and Implementation. Research Reports, No 14, Development Policy Centre, Ibadan

Ajanlekoko, J. S. (2001). Sustainable Housing Development in Nigeria- the Financial and Infrastructural Implication. International Conference on Spatial Information for Sustainable Development. Nairobi, Kenya, 2-5, October.

Aluko (2004), housing and urban development in Nigeria. Ibadan; kins publication.

Aribigbola, A. (2008). Housing Policy Formulation in Developing Countries: Evidence of Programme Implementation from Akure, Ondo State, Nigeria. Journal of Human Ecology, 23(2), 125-134.

Choguill, C. L. (2007). The Search for Policies to Support Sustainable Housing. Habitat International, 143-149.

Diogu, J. O. (2002). Housing the Poor in Nigeria: the Integrated Project Approach. Association of Architectural Educators in Nigeria (AARCHES) Journal, 2(1), 1-6

Fadahunsi S. O. (1985). Fifty Years of Housing in Nigeria. In Housing in Nigeria, edited by Onibokun 'Poju (Ed.), Nigerian Institute of Social and Economic Research (NISER), Ibadan, 105-132

Gyuse, T. T. (1984). Dimension of Urban Housing Problems in Nigeria. Publication No. 2, Urban Studies Series, National Institute for Policy and Strategic Studies, Kuru,

Ibem, E. O. (2011). Challenges in Public Housing Provision in the Post Independence Era in Nigeria. International Journal of Human Sciences, 8(2), 421-443

Ibrahim, K., \& Mbamali, I. (2013). Availability of Housing Financing Funds for Private Estate Developers in Abuja, Nigeria. Sustainable Building Conference 2013, Coventry University.

Isimi, B. (2005). The Role of the Private Sector in Housing Delivery in Nigeria. Journal of the Nigerian Institute of Architects, 4(4), 6-8

Itam, E. B. (2014). Access to Affordable Housing for Urban Dwellers in Nigeria and the Challenge of the $21^{\text {st }}$ Century".[On Line URL. www. nsecalabar.org/.../Arc_E_Ham_S_Paper.] accessed on November 14, 2014.

Lele, S. M. (1991). Sustainable Development: A Critical Review. World Development, 19(6), 607-621.

Mabogunje, A. L. (2008). Addressing Finance and Resources Constraints for Housing and Urban Development in 
Africa. Keynote Address Delivered at the Experts Session of the African Ministerial Conference on Housing and Urban Development (Amchud)II: Abuja, Nigeria.

Marris, P. (1985). Family and Social Change in African City: A Study of Rehousing in Lagos. London: Routledge and Kegan Paul.

Musari, O. A. (1993). A Critical Analysis of Federal Government of Nigeria Housing Policies and Programmes (1880-1991). A Dissertation Submitted in Partial Fulfillment of the Professional Diploma of the Nigerian Institute of Town Planners and Town Planners Registration

Ndubueze, O. J. (2009). Urban Housing Affordability and Housing Policy Dilemmas in Nigeria, Unpublished Ph.D Thesis, Birmingham: University of Birmingham.

Nubi, O. T. (2008). Affordable Housing Delivery in Nigeria. The South African Foundation International Conference and Exhibition, Cape Town, October, pp. 1-8

Ojonemi P. S., \& Ogwu S.O. (2003). Rural Development Policies and the Challenges of Realizing the Millenium Development Goals in Nigeria. Mediterranian Journal of social Sciences, 4(2), 643-648.

Olayiwola L. M., Adeleye O., \& L. Ogunshakin (2005). Public Housing Delivery in Nigeria: Provision and Challenges. XXXIIIIAHS World Congress on Housing: Transforming Housing Environments through the Design. September 27-30, 2005, Pretoria, South Africa.

Olotuah, O. A. (2009). Demystifying the Nigerian Urban Housing Question. Inaugural Lecture Series 53. Federal University of Technology, Akure, Nigeria.

Onibokun A. (1985). Housing Needs and Response: A Planner's Viewpoints. In Housing in Nigeria, edited by Onibokun 'Poju, 65-83. Nigerian Institute of Social and Economic Research (NISER), Ibadan.

Onibokun, A. G. (1985). Housing in Nigeria. Nigeria Institute for Social and Economic Research (NISER), Ibadan.

Otubu, A. K. (2010). Landuse Policy Administration and Problem of Adequate Housing in Nigeria. Unpublished M.Phil Thesis Submitted to the Faculty of Law, Obafemi awolowo University, Ile Ife.

Oyeshola, D. (2008). Sustainable Development: Issues and Challenges for Nigeria. Ibadan: Daily Graphics Nigeria Ltd.

Policygnosis International Policy and Financial Advisory (2011). A Feasibility Study on the Establishment of a Secondary Mortgage Institution in Nigeria. Final Report Submitted to The Company for Habitat and Housing in Africa (Shelter-Afrique).

Torjman, S. (2005). What is Policy? Caledon Institute of Social Policy.

Ukwayi, K. U. Eja, E.E. Ojong, F. E., \& Out, J. E. (2012). An Assessment of Housing Delivery In Nigeria: Federal Mortgage Bank Scenario. Canadian Social Science, 8(6), 68-74.

UN Habitat, (2012). Sustaiable Housing for Sustainable Cities; A Policy Framework for Developing Countries. Nairobi: United Nations Human Settlement Programme (UN-Habitat).

Wahab, K. A. (1983). More than Shelter. Inaugural Lecture, Series 59, Obafemi Awolowo University, Press, Ile Ife

Waziri G. A., \& Roosli, R. (2013). Housing Policies and Programmes in Nigeria: A Review of the Concept and Implementation. Business Management Dynamics, 3(2), 60-68.

Wikipedia (2014). en.m.wikipedia.org/wiki/Housing last modified on 22 june 2014, at 15:21

Wikipedia (2014). en.m.wikipedia.org/wiki/policy. Last modified on 22 july 2014, at 05:24

Table 1. Housing Delivered between the Period 1980-1983 Ranging from one to 3 Bedroom Flat.

\begin{tabular}{lll}
\hline S/N & State & Housing Units Delivered \\
\hline 1 & FCT & 1,908 \\
2 & Anambra & 2,400 \\
3 & Bauchi & 2,400 \\
4 & Bendel & 1,422 \\
5 & Benue & 1,980 \\
6 & Borno & 2,808 \\
7 & Cross River & 2,258 \\
8 & Gongola & 3,038 \\
9 & Imo & 2,758 \\
10 & Kaduna & 2,716 \\
11 & Kano & 1,590 \\
12 & Kwara & 2,462 \\
13 & Lagos & 2634 \\
14 & Niger & 2,692 \\
\hline
\end{tabular}




\begin{tabular}{lll}
\hline 15 & Ogun & 2,160 \\
16 & Ondo & 2,930 \\
17 & Oyo & 2,128 \\
18 & Plateau & 2,546 \\
19 & Rivers & 1,580 \\
20 & Sokoto & 2,314 \\
Total & & 47,500 \\
\hline
\end{tabular}

Source: Waziri and Roosli (2013)

Table 2. Vision 20: 2020 Housing Requirements

\begin{tabular}{lll}
\hline Year & Houses to be Built Nation-Wide & Average Number of Homes per State \\
\hline 2011 & - & - \\
2012 & 500,000 & 12,500 \\
2013 & 600,000 & 15,000 \\
2014 & 720,000 & 18,000 \\
2015 & 864,000 & 21,600 \\
2016 & $1,036,000$ & 25,920 \\
2017 & $1,244,000$ & 31,104 \\
2018 & $1,492,992$ & 37,325 \\
2019 & $1,781,590$ & 44,790 \\
2020 & $2,149,908$ & 53,749 \\
Total & $10,398,650$ & 259,987 \\
\hline
\end{tabular}

Source: Sam Odia, Thisday 3, 2010; Policygnosis International Policy and Financial Advisory (2011)

Table 3. Estimated Housing Needs between the Periods of $1990-2020$

\begin{tabular}{llll}
\hline Income Group & 1990 & 2000 & 2020 \\
\hline Low-Income & $8,413,980$ & $14,372,293$ & $39,989,286$ \\
Medium-Income & $7,770,005$ & $13,273,291$ & $33,573,900$ \\
High-Income & $7,624,230$ & $12,419,068$ & $28,548,633$ \\
\hline
\end{tabular}

Source: Onibokun, 1990

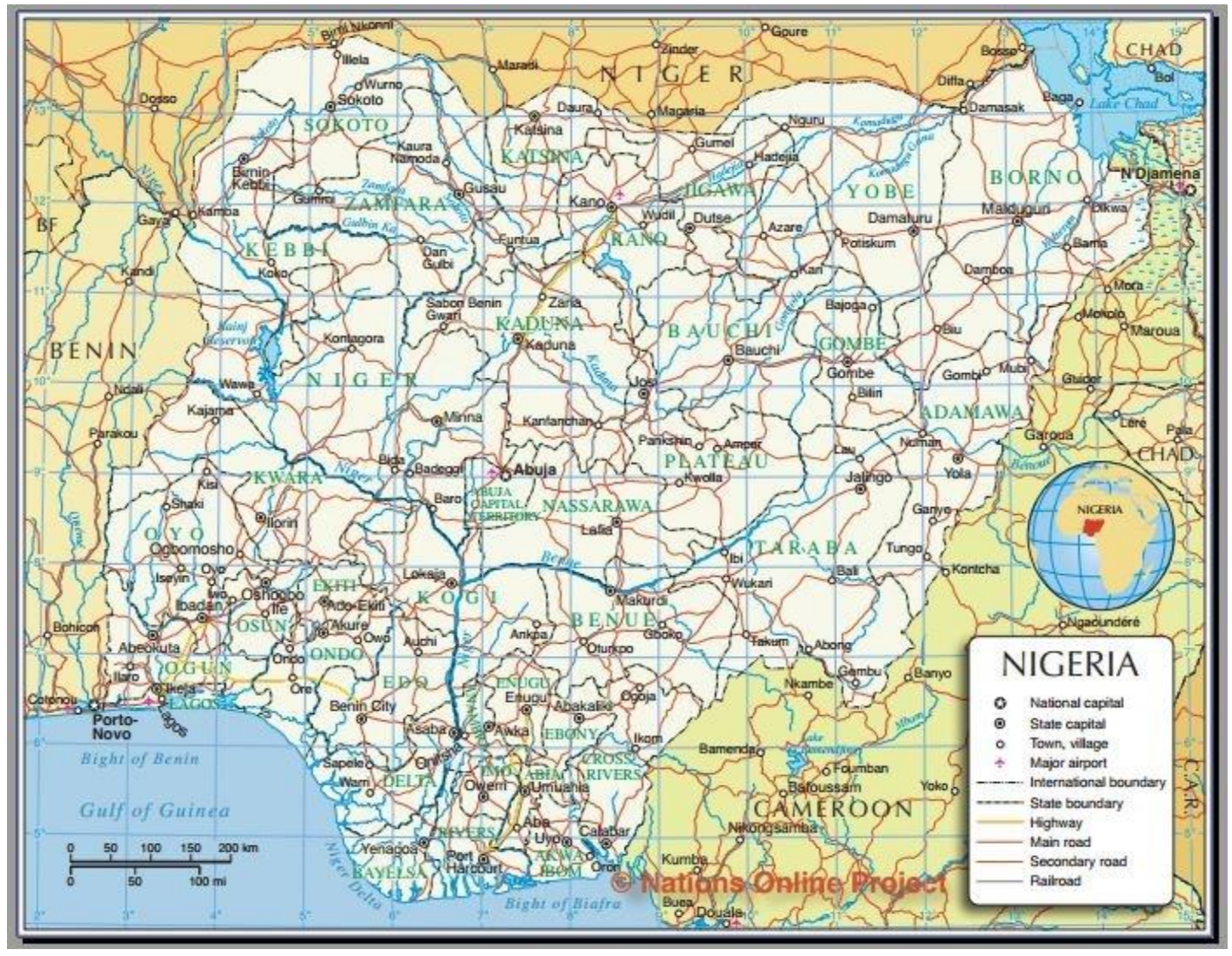

Figure 1. Map of the Study Area

\section{(cc) EY}

This work is licensed under a Creative Commons Attribution 3.0 License. 